\title{
ST
}

Science \& Technology

PAPER - OPEN ACCESS

\section{Uji Fenolik Dan Toksisitas (Brine Shrimp Lethality Test) Ektrak Methanol Daun Benalu Duku Hijau (Dendrohtoe pentandara (L.) Miq) Dan Merah (Scurrula ferruginea (Jack) Danser)}

\author{
Author : Rini Hardiyanti dkk., \\ DOI $\quad: 10.32734 /$ st.v2i1.319 \\ Electronic ISSN $\quad: 2654-7082$ \\ Print ISSN : :2654-7074
}

Volume 2 Issue 1-2018 TALENTA Conference Series: Science \& Technology (ST)

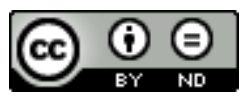

This work is licensed under a Creative Commons Attribution-NoDerivatives 4.0 International License.

Published under licence by TALENTA Publisher, Universitas Sumatera Utara

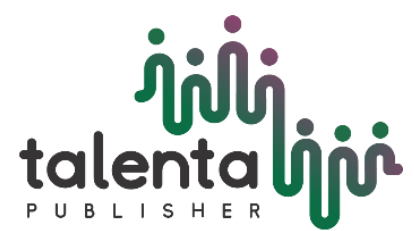




\title{
Uji Fenolik Dan Toksisitas (Brine Shrimp Lethality Test) Ektrak Methanol Daun Benalu Duku Hijau (Dendrohtoe pentandara (L.) Miq) Dan Merah (Scurrula ferruginea (Jack) Danser)
}

\author{
Rini Hardiyanti ${ }^{\mathrm{a}^{*}}$, Lamek Marpaung ${ }^{\mathrm{b}}$, I Ketut Adnyana ${ }^{\mathrm{c}}$, Partomuan Simanjuntak ${ }^{\mathrm{d}}$ \\ ${ }^{a}$ Mahasiswa Pascasarjana Program Doktor Ilmu Kimia USU, Medan \\ ${ }^{b}$ Fakultas Matematika dan Ilmu Pengetahuan Alam, USU, Medan \\ ${ }^{c}$ Fakultas Farmasi, ITB, Bandung \\ ${ }^{d}$ Pusat Penelitian Bioteknologi, LIPI Cibinong
}

rinihardiyanti99@yahoo.com, toyamaikayakadai@yahoo.co.id, ketut@fa.itb.ac.id,partomsimanjuntak@gmail.com

\begin{abstract}
Abstrak
Uji fenolik ekstrak dilakukan dengan menggunakan $\mathrm{FeCl}_{3}$ untuk mengetahui kandungan senyawa fenolik dari daun benalu duku hijau (Dendrophthoe pentandara (L.) Miq) dan daun benalu duku merah (Scurrula ferruginea (Jack) Danser) serta efek toksisitas telah diamati dengan metode Brine Shrimp Lethality Test (BSLT). Daun benalu duku diekstrak hingga diperoleh ekstrak methanol. Hasil pengujian ekstrak methanol menunjukkan bahwa ekstrak benalu duku hijau dan merah mempunyai potensi sitotoksik terhadap larva udang dengan nilai LC 50 masing-masing 13.95 ppm dan 22.37 ppm. Hasil tersebut menunjukkan bahwa ekstrak daun benalu duku hijau (Dendrophthoe pentandara (L.) Miq) bersifat lebih toksik dibandingkan ekstrak daun benalu duku merah (Scurrula ferruginea (Jack) Danser).
\end{abstract}

Kata Kunci : Uji Fenolik; Toksisitas; Ekstrak Methanol Daun Benalu Duku;

\section{Pendahuluan}

Benalu duku (Dendrophthoe pentandra (L.) Miq) adalah tumbuhan parasit yang termasuk dalam 3000 spesies tumbuhan lain yang memiliki potensi sebagai obat. Benalu duku biasanya dianggap parasit pada tanaman duku dan sering dibuang karena dianggap mengganggu pertumbuhan tanaman duku. Namun, daun benalu yang selama ini dinggap parasit ternyata memiliki khasiat bagi kesehatan manusia, yaitu dapat berfungsi sebagai penghambat laju pertumbuhan sel kanker [1].

Saat ini telah dilakukan penelitian terhadap kandungan daun benalu duku yang dapat berfungsi sebagai tanaman obat. Berbagai penelitian membuktikan bahwa kandungan bahan yang terdapat di dalam benalu duku mampu menghambat sel kanker. Diketahui bahwa di dalam daun benalu duku terdapat senyawa flavonoida yaitu kersetrin yang diyakini dapat berfungsi sebagai senyawa antikanker. Saat ini, masyarakat banyak mengkonsumsi air seduhan dari daun benalu duku sebagai senyawa antikanker khususnya antikanker payudara. Ekstrak methanol daun benalu duku (Loranthaceae dendrophthoe spec.,) kadar $20 \mu \mathrm{g} . \mathrm{ml}^{-1}$, memiliki potensi daya hambat pertumbuhan sel myeloma secara in vitro [2][3].

Saat ini telah dilakukan penelitian terhadap metabolik sekunder suatu tanaman yang dapat dimanfaatkan [4][5].Untuk itu, perlu dilakukan uji pendahuluan untuk mengetahui aktivitas senyawa flavonoid yang terdapat pada daun benalu duku sebagai antikanker dengan menguji toksisitas dan aktivitas antioksidannya. 
Peranan antioksidan sangat penting dalam meredam efek radikal bebas yang berkaitan erat dengan terjadinya penyakit degeneratif seperti tekanan darah tinggi, jantung koroner, diabetes dan kanker yang didasari oleh proses biokimiawi dalam tubuh [6]. Radikal bebas yang dihasilkan secara terus menerus selama proses metabolisme normal, dianggap sebagai penyebab terjadinya kerusakan fungsi sel-sel tubuh yang akhirnya menjadi pemicu timbulnya penyakit degeneratif. Reaksi radikal bebas secara umum dapat dihambat oleh antioksidan tertentu baik alami maupun sintetis. Sebahagian besar antioksidan alami berasal dari tanaman, antara lain berupa senyawaan tokoferol, karatenoid, asam askorbat, fenol, dan flavonoid [7].

Senyawa bioaktif hampir selalu toksik pada dosis tinggi, oleh karena itu daya bunuh in vivo dari senyawa terhadap organisme hewan dapat digunakan untuk menapis ekstrak tumbuhan yang mempunyai bioaktivitas dan juga memonitor fraksi bioaktif selama fraksinasi dan pemurnian. Salah satu organisme yang sesuai untuk hewan uji adalah brine shrimp (udang laut) [8].

\section{Metode Penelitian}

Sampel. Daun Benalu Duku yang digunakan diambil dari tanaman duku yang diperoleh di kecamatan Medan Johor, Kota Medan.

Preparasi Sampel. Sampel daun benalu duku dibersihkan, dikeringanginkan selama 7 x 24 jam, dipotong kecilkecil dan dihaluskan dengan menggunakan blender hingga berbentuk serbuk.

Ekstraksi Sampel. Sampel kering yang telah dihaluskan ditimbang yang kemudian dilakukan teknik maserasi dengan pelarut methanol selama 48 jam. Kemudian disaring sehingga diperoleh ekstrak methanol yang mengandung senyawa flavonoida dari sampel. Ekstrak methanol dipekatkan dengan menggunakan alat Rotari Evaporator dan dipanaskan diatas penangas air. Ekstrak pekat methanol dilarutkan dengan aquadest dan dipartisi dengan etil asetat. Hingga pada larutan aquadest tidak terdapat senyawa flavonoid, maka dideteksi dengan cara mencampur sedikit larutan aquadest dengan pereaksi flavonoid seperti $\mathrm{FeCl}_{3}$ hingga tidak terjadi perubahan warna. Uji positif flavonoid ditandai dengan perubahan warna hitam. Filtrat etil asetat dipekatkan dan kemudian ekstraknya dilarutkan dengan methanol. Kemudian dipartisi kembali dengan n-Heksan untuk memisahkan senyawa nonpolar agar diperoleh senyawa flavonoida total. Flavonoida total di uji dengan KLT [9].

Uji Fenolik. Sebanyak $5 \mathrm{ml}$ ekstrak metanol yang belum dipekatkan dimasukkan ke dalam tabung reaksi, kemudian ditetesi dengan 3 tetes larutan $\mathrm{FeCl}_{3} 1 \%$, hasilnya positif mengandung senyawa fenolik jika terbentuk warna hitam [10].

Uji Toksisitas dengan Metode BSLT. Uji bioaktivitas dilakukan dengan memmasukkan 10 ekor larva udang A. salina Leach yang berumur 48 jam ke dalam botol yang telah berisi larutan ekstrak dan air laut. Untuk setiap konsentrasi dilakukan 3 kali ulangan (triplo). Sebagai control adalah air laut yang tidak diberi ekstrak sampel. Botol percobaan disimpan di bawah pencahayaan lampu TL. Pengamatan dilakukan setelah 24 jam. Jumlah larva udang yang mati dicatat kemudian dihitung persentase kematiannya. Data yang diperoleh diolah dengan menggunakan analisis probit.

Penetasan kista Artemia salina Leach. Kista A. Salina Leach ditimbang kurang lebih $50 \mathrm{mg}$ dan dimasukkan ke dalam gelas piala yang berisi $500 \mathrm{ml}$ air laut yang sudah disaring kemudian dipasang aerator. Biarkan selama 48 jam dengan pencahayaan lampu TL agar menetas sempurna. Larva yang sudah menetas dipipet ke dalam botol percobaan dan diberi ekstrak sesuai perlakuan.

Persiapan Sampel. Pembuatan larutan ekstrak 2000 ppm : sebanyak 40 mg ekstrak ditimbang dengan teliti kemudian dilarutkan dalam $20 \mathrm{ml}$ air laut. Untuk ekstrak yang sukar larut, dapat ditambahkan DMSO $1 \%$ (5 tetes) untuk meningkatkan kelarutan. Konsentrasi 200 ppm dibuat dengan memipet 2 ml larutan ekstrak 2000 ppm dan ditambahkan air laut sampai $20 \mathrm{ml}$. konsentrasi 20 ppm dibuat dengan memipet $2 \mathrm{ml}$ larutan konsentrasi $200 \mathrm{ppm}$ dan ditambahkan air laut sampai $20 \mathrm{ml}$. larutan sampel $1000 \mathrm{ppm}$ dibuat dengan cara memipet $5 \mathrm{ml}$ larutan ekstrak 2000 ppm dan ditambahkan air laut $5 \mathrm{ml}$. konsentrasi 100 ppm dibuat dengan cara memipet larutan ekstrak 200 ppm sebanyak $5 \mathrm{ml}$ dan ditambahkan air laut $5 \mathrm{ml}$. larutan sampel $10 \mathrm{ppm}$ dibuat dengan cara memasukkan larutan ekstrak 20 ppm dan ditambahkan $5 \mathrm{ml}$ air laut [8]. 


\section{Hasil dan Pembahasan}

Uji Fenolik. Hasil uji fenolik menunjukkan bahwa daun benalu duku merah dan hijau mengandung senyawa flavonoid yang cukup banyak yang ditunjukkan dengan terbentuknya warna hitam yang pekat.

Uji Toksisitas dengan Metode BSLT. Uji toksisitas ekstrak methanol daun benalu duku hijau dan merah dengan metode BSLT memperlihatkan hasil seperti pada Tabel 1. Dari data pada Tabel 1. Hasil pengujian ekstrak methanol menunjukkan bahwa ekstrak benalu duku hijau dan merah mempunyai potensi sitotoksik terhadap larva udang dengan nilai $\mathrm{LC}_{50}$ masing-masing $13.95 \mathrm{ppm}$ dan $22.37 \mathrm{ppm}$. Hasil tersebut menunjukkan bahwa ekstrak daun benalu duku hijau (Dendrophthoe pentandara (L.) Miq) bersifat lebih toksik dibandingkan ekstrak daun benalu duku merah (Scurrula ferruginea (Jack) Danser). Suatu zat dikatakan aktif atau toksik bila nilai $\mathrm{LC}_{50}<1000 \mathrm{ppm}$ untuk ekstrak dan $<30$ ppm untuk suatu senyawa [11].

Tabel 1. Hasil Uji Toksisitas Ekstrak Ekstrak Daun Benalu Duku Hijau dan Merah dengan Metode BSLT

\begin{tabular}{|c|c|c|c|c|c|}
\hline Nama Sampel & $\mathrm{K}(\mathrm{ppm})$ & Mati & Total Larva & Mortalitas (\%) & $\mathrm{LC}_{50}(\mathrm{ppm})$ \\
\hline \multirow{3}{*}{$\begin{array}{l}\text { Daun Benalu Duku } \\
\text { Hijau }\end{array}$} & 1000 & 28 & 30 & 93.33 & \multirow{3}{*}{13.95} \\
\hline & 100 & 22 & 30 & 73.33 & \\
\hline & 10 & 17 & 30 & 56.67 & \\
\hline \multirow{3}{*}{$\begin{array}{l}\text { Daun Benalu Duku } \\
\text { Merah }\end{array}$} & 1000 & 26 & 30 & 86.67 & \multirow{3}{*}{22.37} \\
\hline & 100 & 19 & 30 & 63.33 & \\
\hline & 10 & 13 & 30 & 43.33 & \\
\hline \multirow{3}{*}{ Kontrol Positif } & 1000 & 0 & 30 & 0.00 & \multirow{3}{*}{-} \\
\hline & 100 & 0 & 30 & 0.00 & \\
\hline & 10 & 0 & 30 & 0.00 & \\
\hline \multirow{3}{*}{ Kontrol Negatif } & 1000 & 0 & 30 & 0.00 & \multirow{3}{*}{-} \\
\hline & 100 & 0 & 30 & 0.00 & \\
\hline & 10 & 0 & 30 & 0.00 & \\
\hline
\end{tabular}

Keterangan :

$\mathrm{K}=$ Konsentrasi

LC50 $=$ Lethal Concentration 50

Kriteria nilai LC 50 untuk uji toksisitas menurut Meyer adalah sebagai berikut:

LC $50<1.000 \mathrm{ppm}$ bersifat toksik

LC $50>1.000$ ppm bersifat non toksik

Kriteria nilai LC 50 untuk uji toksisitas menurut Clarkson adalah sebagai berikut:

LC $50>1.000$ ppm bersifat non toksik

LC 50 500-1.000 ppm bersifat toksik rendah

LC 50 100-500 ppm bersifat toksik sedang

LC 50 0-100 ppm bersifat sangat toksik

Dari kriteria diatas, nilai LC50 berdasarkan uji toksisitas menggunakan metode BSLT diketahui bahwa ekstrak daun benalu duku yang diuji termasuk dalam kategori toksik menurut Meyer dan sangat toksik menurut Clarkson. Sifat toksik diperkirakan disebabkan oleh senyawa kersetin pada daun benalu duku. 


\section{Kesimpulan}

Dari uji toksisitas menggunakan metode BSLT diketahui bahwa pada ekstrak methanol, benalu duku hijau dan merah mempunyai potensi sitotoksik terhadap larva udang dengan nilai $\mathrm{LC}_{50}$ masing-masing $13.95 \mathrm{ppm}$ dan 22.37 ppm. Hasil tersebut menunjukkan bahwa ekstrak daun benalu duku hijau (Dendrophthoe pentandara (L.) Miq) bersifat lebih toksik dibandingkan ekstrak daun benalu duku merah (Scurrula ferruginea (Jack) Danser).

\section{Referensi}

[1] Pattanayak S P and Sunita P 2008 Wound healing, anti-microbial and antioxidant potential of Dendrophthoe falcata (L.f) Ettingsh J. Ethnopharmacol. $120241-7$

[2] Puneetha G K, Thriveni M C, Murali M, Shivamurthy G R, Niranjana S R, Prakash H S, Sadashiva M P and Amruthesh K N 2013 Evaluation of a parasitic flowering plant Dendrophthoe trigona (Wt. \&amp; Arn.) Danser for its phytochemical and antioxidant activities $J$. Pharm. Res. 7 20-3

[3] Sathishkumar G, Gobinath C, Wilson A and Sivaramakrishnan S 2014 Dendrophthoe falcata (L.f) Ettingsh (Neem mistletoe): A potent bioresource to fabricate silver nanoparticles for anticancer effect against human breast cancer cells (MCF-7) Spectrochim. Acta - Part A Mol. Biomol. Spectrosc. 128 285-90

[4] Prasetya A T, Mursiti S, Maryan S and Jati N K 2018 Isolation and Identification of Active Compounds from Papaya Plants and Activities as Antimicrobial IOP Conf. Ser. Mater. Sci. Eng. 349012007

[5] D P Putri, Y Widyastuti W S and Yunus D and A 2018 The effect of shade and vermicompost application on yield and flavonoid levels of Tempuyung ( Sonchus arvensis ) The effect of shade and vermicompost application on yield and flavonoid levels of Tempuyung ( Sonchus arvensis )

[6] Saleh S A 2017 Original Article CHEMICAL CONSTITUENTS , IN VITRO ANTIOXIDANT ACTIVITY, ORAL ACUTE TOXICITY AND LD 50 DETERMINATION OF MORINGA OLEIFERA LEAVES 9

[7] Sembiring H B, Barus T and Marpaung L 2015 Antioxidant and Antibacterial Activity of Some Leaves Extracts ( Methanol , Ethyl Acetate and N-Hexane ) of Int. J. PharmTech Res. 8 24-30

[8] Rini Hardiyanti, Lamek Marpaung, Partomuan Simanjuntak I K A 2017 Duku's Mistletoe Leaf (Dendrophthoe pentandara (L.) Miq) (Lorhantaceae) as a Cancer Prevention Drugs The 7th AIC-ICMR on Health and Life Sciences The Annual International Conference 2017 Syiah Kuala University pp 45-53

[9] Lubis M Y, Siburian R, Marpaung L, Simanjuntak P and Nasution M P 2018 Methyl Gallate From Jiringa (Archidendron Jiringa) and Antioxidant Activity. Asian J. Pharm. Clin. Res. 11346

[10] Yuvianti Dwi Franyoto, Lia Kusmita, Mutmainah R D A 2018 Total flavonoid content and formulation antioxidant cream stem of jatropha multifida 1

[11] Rohim P, Arung E T and Kusuma I W 2018 Potential of antioxidant and toxicity of some medical plants used by sub-ethnic communities of Bahau in East Kalimantan IOP Conf. Ser. Earth Environ. Sci. 144 